\title{
Pengembangan Desain Produk Berbahan Pelepah Pisang Untuk Meningkatkan Daya Saing Usaha Kecil
}

\author{
Bambang Tristiyono, Bambang Mardiono Soewito, Hertina Susandari, \\ Thomas Ari Kristianto dan Aria Weny Anggraita \\ Departemen Desain Produk Industri, Fakultas Arsitektur Desain dan Perencanaan, \\ Institut Teknologi Sepuluh Nopember \\ e-mail: gacombi@prodes.its.ac.id
}

\begin{abstract}
Abstrak-Industri kreatif adalah industri yang berasal dari pemanfaatan kreativitas, keterampilan serta bakat individu untuk menciptakan nilai ekonomi serta lapangan pekerjaan dengan menghasilkan dan mengeksploitasi daya kreasi dan daya cipta individu tersebut. Industri kreatif semakin penting dalam mendukung kesejahteraan dalam perekonomian bangsa. Program ini membantu mengembangkan mitra usaha kecil untuk mandiri secara ekonomi, berbasis kompetensinya dan berkelanjutan, meningkatkan ketrampilan berpikir dalam mengolah peluang pasar, sehingga dapat diwujudkan menjadi produk yang potensial di pasar. Metode yang direncanakan untuk mencapai tujuan tersebut adalah membimbing mitra dalam meningkatkan kualitas produk dengan membuat variasi desain khusus (unik) yang berbeda dengan produk sebelumnya dengan target pasar yang spesifik (ceruk pasar). Hal ini dimaksudkan untuk mengurangi resiko produk tidak diminati konsumen/pasar, karena dasar penciptaan ide desain adalah keinginan/kebutuhan konsumen. Dengan desain yang spesifik, unik dan berorientasi konsumen, diharapkan mitra usaha kecil bisa mengekploitasi potensinya, sehingga memiliki daya saing untuk bertahan hidup dan berkembang menjadi besar. Program ini dimaksudkan dapat membantu Mitra dalam menghasilkan desain produk yang lebih variatif dan ekploratif, serta mempunyai nilai fungsi yang berbasis keinginan dan kebutuhan konsumen, dengan harapan penjualan akan semakin meningkat dan Mitra menjadi berkembang, sehingga nantinya bisa menjadi contoh dan dapat diterapkan untuk usaha kecil sejenis yang lain.
\end{abstract}

Kata kunci: desain produk, industri kreatif dan usaha kecil

Abstract-Creative industry is an industry derived from the utilization of creativity, skills and individual talents to create economic value and employment by generating and exploiting the creative power and creativity of the individual. Creative industry is increasingly important in supporting prosperity in the nation's economy. This program helps develop small business partners to be economically independent, competence-based and sustainable, improve thinking skills in processing market opportunities, so that it can be realized into potential products in the market. The program is also expected to increase the knowledge of small business partners in the creativity of product creation, management and marketing aspects so that it is expected to manage more professional business with better targets. The method to achieve that goal is to guide partners in improving product quality by creating unique design variations that are different from the previous product with a specific target market (niche market). This is intended to reduce the risk of products not interested consumers / markets, because the basis of the creation of design ideas is the desire / needs of consumers. Specific design, unique and consumer-oriented, small business partners are expected to exploit its potential, so it has the competitiveness to survive and grow into large. This programs are intended to assist Partners in producing more varied and explorative product designs, and have value functions based on the wants and needs of consumers, in the hope that sales will increase and partners grow, so it can be an example and can be applied to another similar small businesses.

Key word: product design, creative industry, and small businesses

\section{PENDAHULUAN}

Berawal dari gebrakan di Inggris, ekonomi atau industri kreatif kini banyak diadopsi negara-negara berkembang termasuk Indonesia. Dengan komposisi jumlah penduduk usia muda sekitar 43 persen (sekitar 103 juta orang), Indonesia memiliki basis sumber daya manusia cukup banyak bagi pengembangan ekonomi kreatif. Industri Kreatif merupakan kelompok industri yang terdiri dari berbagai jenis industri yang masing-masing memiliki keterkaitan dalam proses pengeksploitasian ide atau kekayaan intelektual menjadi nilai ekonomi tinggi yang dapat menciptakan kesejahteraan dan lapangan pekerjaan.

Industri kreatif adalah industri yang berasal dari pemanfaatan kreativitas, keterampilan serta bakat individu untuk menciptakan nilai ekonomi serta lapangan pekerjaan dengan menghasilkan dan mengeksploitasi daya kreasi dan daya cipta individu tersebut. Industri kreatif dipandang semakin penting dalam mendukung kesejahteraan dalam perekonomian bangsa. Survei INSEAD dalam mengukur Indeks Inovasi Global di tahun 2015, mendudukkan Indonesia di peringkat 87 dari 126 negara, meningkat dari peringkat 99 pada 2014. Meskipun Indonesia telah menunjukkan peningkatan, peringkat negara-negara tetangga seperti Vietnam (71) dan Thailand (48) masih tetap unggul dari Indonesia. Sedangkan, peringkat ekspor barang kreatif Indonesia tumbuh menjadi peringkat 25 di tahun 2015 dari peringkat 85 di tahun sebelumnya [1,2].

Cetak biru rencana pengembangan industri kreatif terfokus pada 14 subsektor industri kreatif, yakni arsitektur, desain, fashion, film, video dan fotografi, kerajinan, layanan komputer dan peranti lunak, musik, pasar barang seni, penerbitan dan percetakan, periklanan, permainan interaktif, 
riset dan pengembangan, seni pertunjukan, serta televisi dan radio. Dari 14 subsektor ekonomi kreatif yang dikembangkan, terdapat tiga subsektor yang memberikan kontribusi dominan terhadap PDB, yaitu kuliner sebesar Rp.209 triliun atau 32,5 persen, fesyen sebesar Rp.182 triliun atau 28,3 persen dan kerajinan sebesar Rp.93 triliun atau 14,4 persen. Melihat lebih dalam pada kinerja ekspor industri fesyen dan kerajinan, ekspor industri fesyen mencapai Rp.76,7 triliun atau meningkat 8 persen pada tahun 2016. Sejalan dengan fesyen, pada industri kerajinan pun terdapat peningkatan kinerja ekspor yakni mencapai Rp.21,7 triliun atau meningkat 7,6 persen dibandingkan tahun sebelumnya.

Untuk meningkatkan capaian tersebut menjadi lebih baik tentunya perlu kerja lebih keras lagi dan saling bahu membahu antar pihak yang saling berkepentingan. Industri kerajinan akan menjadi fokus dalam program kegiatan ini dan pelaku usaha ini tersebar di seluruh pelosok nusantara, terutama di daerah-daerah yang mempunyai sumber daya lokal yang bisa diandalkan, salah satu contohnya adalah potensi pengrajin pelepah pisang di Bojonegoro $[3,4,5$ dan 6].

Dari observasi awal yang dilakukan ternyata bahan pelepah pisang di kabupaten Bojonegoro adalah terbaik di Indonesia, terutama yang tumbuh disekitar pegunungan kapur. Dari hasil uji penelitian yang dilakukan oleh tim Institut Teknologi Bandung, ternyata pelepah pisang asal Bojonegoro adalah yang terbaik. Hal itu diungkapkan oleh Suyitno (pengrajin pelepah pisang), warga Desa Banjaran, Kecamatan Baureno, Kabupaten Bojonegoro yang juga menjadi mitra program kegiatan ini. Suyitno sendiri adalah pelaku budi daya pelepah pisang yang telah sukses mengembangkan kerajinan dari kulit pohon pisang tersebut. "Memang pernah diteliti ITB, dan diakui pelepah yang ada di Bojonegoro adalah yang terbaik," ujarnya. Kerajinan Pelepah pisang ini, mampu mencapai pasar internasional, seperti negara-negara di Amerika, Australia dan Jerman, yang pemasarannya langsung diambil oleh pengepul, disamping juga melayani pesanan dari berbagai daerah, khususnya di Jawa Timur.

Tabel 1. Tahapan kegiatan riset

\begin{tabular}{|c|c|c|c|}
\hline No. & Kegiatan & Luaran & $\begin{array}{c}\text { Indikator } \\
\text { capaian (KPI) }\end{array}$ \\
\hline 1 & $\begin{array}{l}\text { Studi lapangan, } \\
\text { survei pasar, } \\
\text { Benchmark } \\
\text { Competitor. }\end{array}$ & \multirow[t]{2}{*}{$\begin{array}{l}\text { Analisa } \\
\text { MSCA }\end{array}$} & \multirow{2}{*}{$\begin{array}{l}\text { - Terdefinisinya } \\
\text { MSCA } \\
\text { Analisis } \\
\text { - Terdefinisinya } \\
\text { Prioritas } \\
\text { Kebutuhan \& } \\
\text { Konsep Desain }\end{array}$} \\
\hline 2 & $\begin{array}{l}\text { Studi kebutuhan, } \\
\text { brainstorming ideas, } \\
\text { product positioning. }\end{array}$ & & \\
\hline 3 & $\begin{array}{l}\text { Explorasi ide \& } \\
\text { sketsa desain }\end{array}$ & \multirow[t]{2}{*}{$\begin{array}{l}\text { Altematif } \\
\text { desain }\end{array}$} & \multirow[t]{2}{*}{$\begin{array}{l}\text { Adanya } 3 \text { (tiga) } \\
\text { altematif desain }\end{array}$} \\
\hline 4 & Design alternative & & \\
\hline 5 & Design development & \multirow{2}{*}{$\begin{array}{l}\text { Final } \\
\text { Design }\end{array}$} & \multirow{2}{*}{$\begin{array}{l}\text { Terdefinisinya } \\
\text { desain akhir }\end{array}$} \\
\hline 6 & Detailed design & & \\
\hline 7 & $\begin{array}{l}\text { Pembuatan prototipe } \\
\text { Produk }\end{array}$ & \multirow[t]{2}{*}{ Prototipe } & \multirow[t]{2}{*}{$\begin{array}{l}\text { Adanya } \\
\text { prototype produk }\end{array}$} \\
\hline 8 & Finishing & & \\
\hline
\end{tabular}

Namun demikian, dari hasil observasi awal ada beberapa kendala yang membuat usaha para pengrajin kurang bisa berkembang pesat, diantaranya adalah masalah variasi produk yang ditawarkan dan jaringan pemasaranya. Sehubungan dengan masalah tersebut dalam Program Adimas ini kami berencana membuat kegiatan yang dapat membantu usaha pengrajin lokal di Bojonegoro untuk meningkatkan usahanya sehingga bisa berkembang lebih baik, diantaranya yaitu; membuat variasi desain yang lebih ekploratif dalam kuantitas yang cukup banyak, ide yang unik berbasis lokal konten dan budaya Indonesia, serta mempunyai nilai fungsi yang berbasis keinginan dan kebutuhan konsumen. Dengan variasi desain yang cukup dan menarik diharapkan pengrajin mempunyai cukup persediaan produk yang akan dipasarkan untuk menarik minat konsumen. Sebagai catatan, selama ini pengrajin lebih pasif kondisinya dan menunggu pesanan, sehingga kondisi usahanya cenderung stagnasi.

\section{METODE}

Urutan tahapan- tahapan yang dilaksanakan adalah sebagai berikut [6]:

1. Studi lapangan, survei pasar, benchmark competitor

2. Studi kebutuhan, brainstorming ideas, product positioning

3. Explorasi ide \& sketsa desain

4. Design alternative

5. Design development

6. Detailed design

7. Pembuatan prototipe produk

8. Finishing

Secara lengkap rencana kegiatan disajikan dalam Tabel 1

\section{HASIL DESAIN}

\section{A. Deskripsi kebutuhan desain}

Hasil studi kebutuhan desain dapat dilihat pada Tabel 2.

Tabel 2. Kebutuhan desain

\begin{tabular}{|c|c|c|c|}
\hline \multicolumn{2}{|c|}{ Atribut Kebutuhan } & Index of & Deskripsi \\
\hline \multirow{3}{*}{ 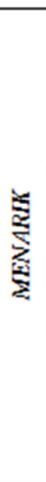 } & Bentuk unik & 4 & $\begin{array}{l}\text { Penting karena bentuk yang } \\
\text { unik akan menjadi ciri khas } \\
\text { yang selalu dimgat dan } \\
\text { dapat meningkatkan daya } \\
\text { tarik konsumen untuk } \\
\text { membeli. }\end{array}$ \\
\hline & $\begin{array}{l}\text { Komposisi wama } \\
\text { tidak monoton, } \\
\text { alami dan khas }\end{array}$ & 5 & $\begin{array}{l}\text { Sangat penting karena wama } \\
\text { adalah keunggulan dari } \\
\text { produk berbahan pelepah } \\
\text { pisang sebagai nilai } \\
\text { pembeda dari produk } \\
\text { lainnya. }\end{array}$ \\
\hline & Detil Tampilan & 4 & $\begin{array}{l}\text { Penting karena detil } \\
\text { tampilan dapat menjadi } \\
\text { faktor pembeda bagi nilai } \\
\text { sebuah produk dan untuk } \\
\text { produk berbahan pelepah } \\
\text { pisang imi penting. }\end{array}$ \\
\hline \multirow{2}{*}{ స̇. } & $\begin{array}{l}\text { Mudah dikenali } \\
\text { penggunaanya }\end{array}$ & 4 & $\begin{array}{l}\text { Penting karena agar } \\
\text { pengguna tidak bingung saat } \\
\text { menggunakanya dan desain } \\
\text { menjadi lebih familiar. }\end{array}$ \\
\hline & $\begin{array}{l}\text { Mempunyai } \\
\text { fungsi }\end{array}$ & 5 & $\begin{array}{l}\text { Sangat penting karena } \\
\text { dengan adanya tambahan } \\
\text { fungsi akan membuat desain } \\
\text { lebih bernilai dan menarik } \\
\text { bagi pengguna. }\end{array}$ \\
\hline
\end{tabular}


Keterangan:

Skala index of interest: 1=sangat tidak penting, 2=tidak penting, $3=$ cukup penting, $4=$ penting, $5=$ sangat penting.

Sumber penilaian: stakeholder, expert source, design reference.

\section{B. Eksplorasi sketsa ide}

Hasil ekplorasi ide pengembangan produk dapat dilihat pada Gambar-gambar 1, 2, 3, 4, 5 dan 6.

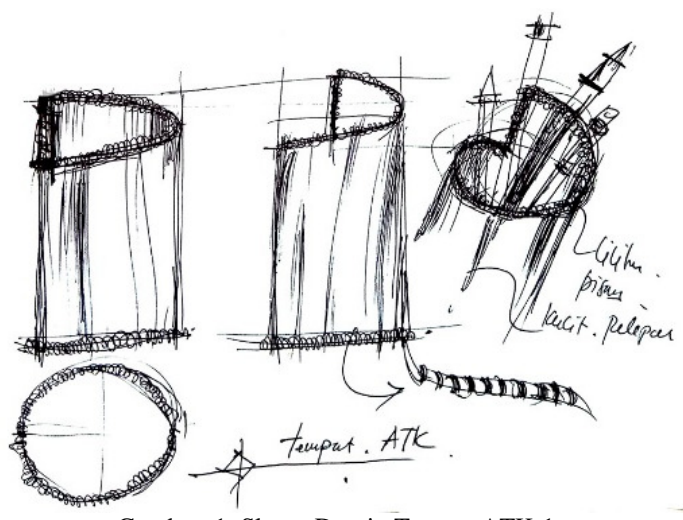

Gambar. 1. Sketsa Desain Tempat ATK-1

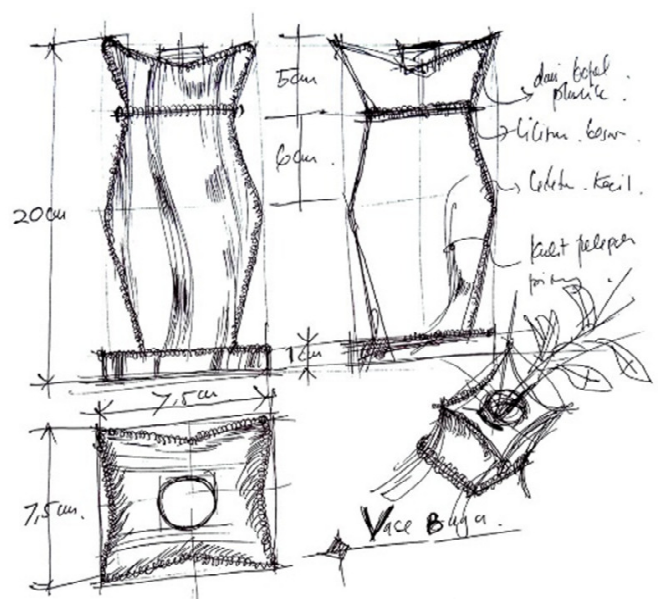

Gambar. 2. Sketsa Desain Vase Bunga

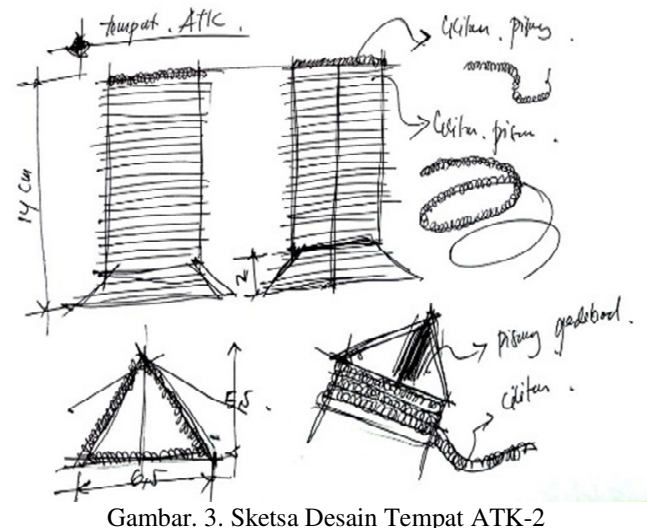

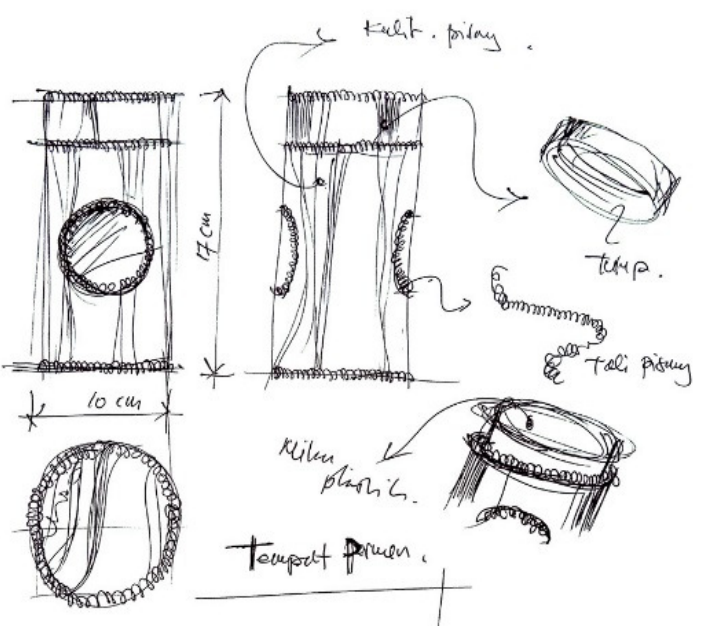

Gambar. 4. Sketsa Desain Tempat Permen

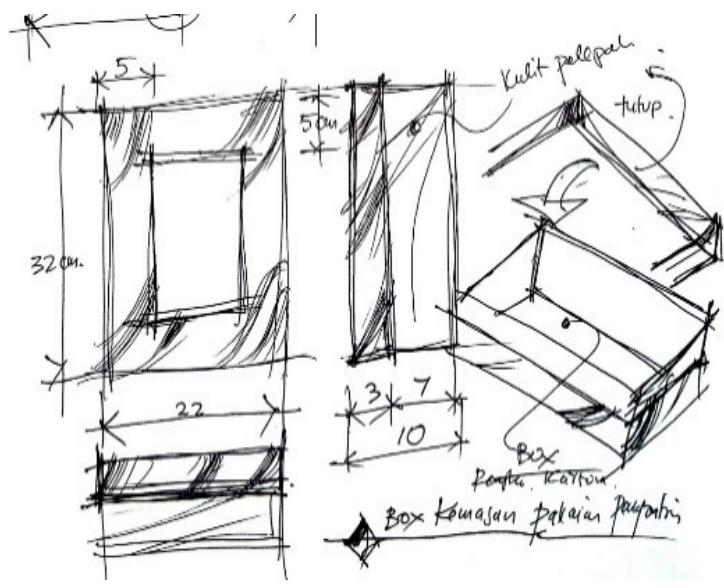

Gambar. 5. Sketsa Desain Kotak Pakaian Pengantin

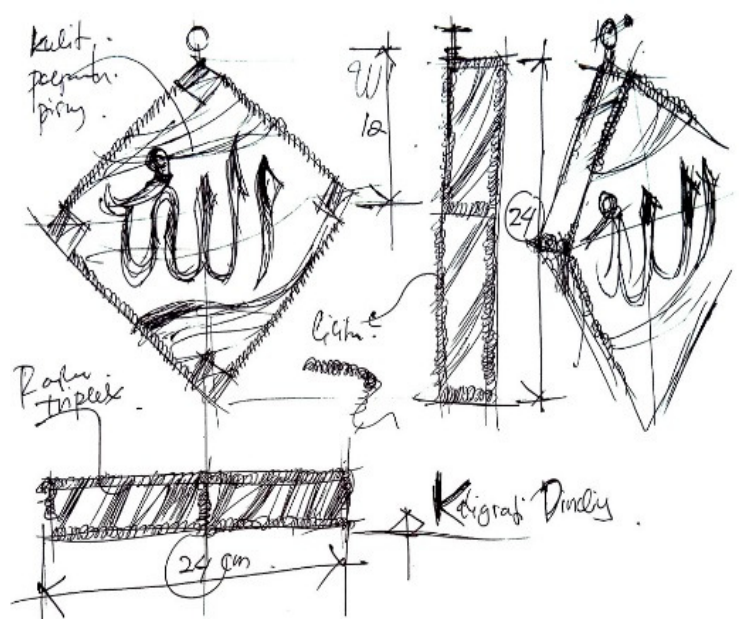

Gambar. 6. Sketsa Desain Kaligrafi Dinding 


\section{Hasil prototipe produk}

Gambar-gambar 7, 8 dan 9 menunjukkan hasil protipe produk yang berhasil diwujudkan.
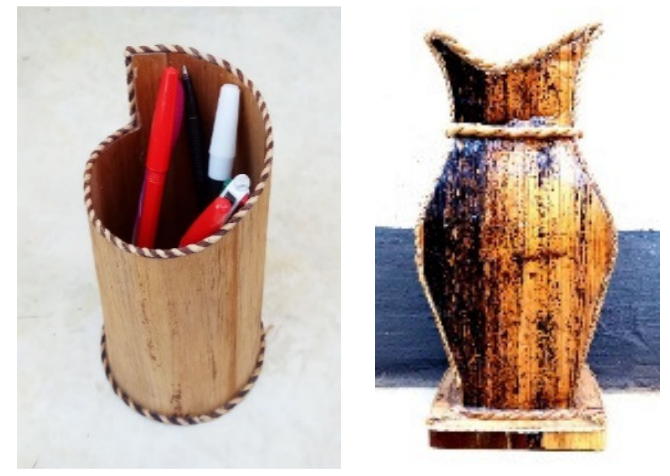

Gambar. 7. Prototipe-tempat ATK dan vase bunga
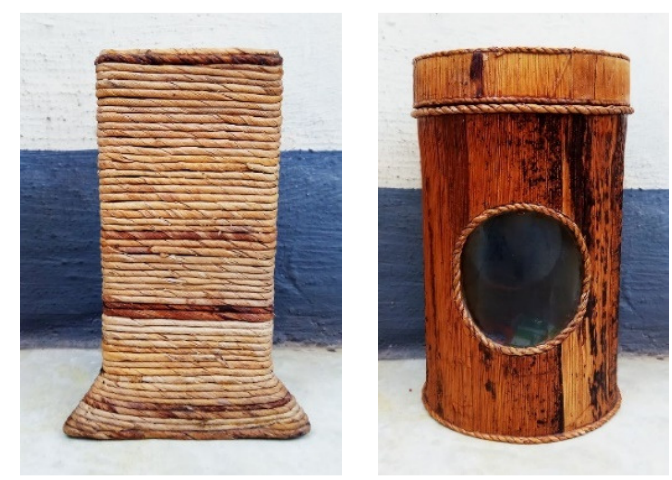

Gambar. 8. Prototipe-tempat ATK dan permen
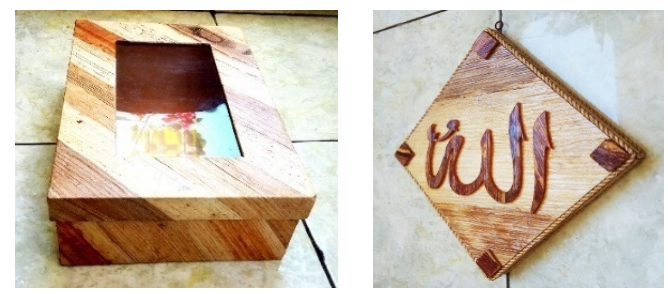

Gambar. 9. Prototipe-kotak pakaian pengantin dan kaligrafi dinding

\section{KESIMPULAN}

Beberapa hal yang dapat disimpulkan dari uraian sebelumnya adalah sebagai berikut:

1. Industri kreatif adalah industri yang berasal dari pemanfaatan kreativitas, keterampilan serta bakat individu untuk menciptakan nilai ekonomi serta lapangan pekerjaan dengan menghasilkan dan mengeksploitasi daya kreasi dan daya cipta individu tersebut. Industri kreatif semakin penting dalam mendukung kesejahteraan dalam perekonomian bangsa.
2. Strategi yang akan dilaksanakan untuk mewujudkan tujuan kegiatan pengabdian adalah membimbing Mitra dalam meningkatkan kualitas produk dengan membuat variasi desain khusus (unik) yang berbeda dengan produk sebelumnya dengan target pasar yang spesifik (ceruk pasar). Hal ini dimaksudkan untuk mengurangi resiko produk tidak diminati konsumen/pasar, karena dasar penciptaan ide desain adalah keinginan/kebutuhan konsumen. Dengan desain yang spesifik, unik dan berorientasi konsumen, diharapkan mitra usaha kecil bisa mengekploitasi potensinya, sehingga memiliki daya saing untuk bertahan hidup dan berkembang menjadi besar.

Beberapa langkah-langkah strategis yang menjamin keberlanjutan program adalah:

1. Diprogramkan konsultasi gratis bagi pengrajin/usaha kecil, bila ada permasalahan yang terjadi, baik secara online atau bimbingan langsung.

2. Usaha Mitra mempunyai pasar yang special karena sifatnya yang unik dan orisinal karena dikerjakan secara manual dan kustom (khas pengrajin), sehingga variasi desain yang mempunyai kharakter khas berbasis lokal konten dan budaya akan menciptakan daya saing, pelanggan loyal (loyalty customer) dan berkelanjutan.

3. Bahan baku yang melimpah dan berkualitas di daerah Mitra pada khususnya, sehingga kebutuhan bahan baku produksi akan tercukupi.

\section{UCAPAN TERIMA KASIH}

Program ini dibiayai oleh: Lembaga Penelitian dan Pengabdian Kepada Masyarakat, Institut Teknologi Sepuluh Nopember, Kementerian Riset, Teknologi dan Pendidikan Tinggi, Sesuai dengan Kontrak Pengabdian, Nomor: 704/PKS/ITS/2017.

\section{DAFTAR PUSTAKA}

[1] antaranews.com (2017), "Ini Kontribusi Industri Kreatif di Perekonomian Indonesia", available on: http://www.antaranews.com/berita/511673/ini-kontribusi industri-kreatif-di-perekonomian-indonesia, 21 Feb. 2017, $16.50 \mathrm{wib}$

[2] swa.co.id (2017), "Strategi Pemerintah Dan Swasta Kembangkan Industry Kreatif", available on: http://swa.co.id/swa/trends/management/strategi-pemerintahdan-swasta-kembangkan-industri-kreatif, 21 peb 2017, 16.30 wib

[3] Bambang Mardiono S, Bambang Tristiyono; Tim (2011), "Eksplorasi Serat Pelepah Pisang Sebagai Aksesoris Pengembangan Produk Tempat Tisu Untuk Café dan Rumah Tangga", Riset Perancangan Produk 4 - Despro ITS, 2013.

[4] Bambang Tristiyono, Thomas Ari K; Tim (2013), "Eksplorasi Glugu dan Limbah Jati sebagai Material Eco-design Produk Stationery untuk Perkantoran", Riset Perancangan 4- Despro ITS, 2014.

[5] Bambang Tristiyono, Aria Weny A; Tim (2012), "Desain Tas Laptop Berkonsep Nusantara Dengan Image Baru Berbahan Dasar Enceng Gondok", Riset Perancangan 4- Despro ITS, 2012.

[6] Norman, Donald Arthur (2005). Emotional Design. Basic Books. ISBN 0465051367. Available on: http://ubiquity.acm.org/article.cfm?id=966013 